\title{
BIPOLARIS HAWAIIENSIS (BUGNICOURT EX M.B. Ellis) UCHIDA \& ARAGAKI - A NEW RECORD OF HUMAN PATHOGENIC SPECIES OF BIPOLARIS IN BANGLADESH
}

\author{
Shamim Shamsi* and Fatema Yeasmin \\ Department of Botany, University of Dhaka, Dhaka-1000. Bangladesh
}

Key words: Bipolaris hawaiiensis, New record, Hyphomycetes, Bangladesh

Bipolaris hawaiiensis (Bugnicourt ex M.B. Ellis) Uchida \& Aragaki is a human pathogenic fungus under the class Hyphomycetes. It is usually found in plants and soil. The fungus is responsible for allergic bronchopulmunary mycoses. It has been reported to cause subcutaneous infections, nasal pheohyphomycoses, corneal ulcers and allergic fungal sinusitis(1-3). Occurrence of B. hawaiiensis in Bangladesh has not yet been reported. However, several phytopathogenic species of Bipolaris occur in the country. Bipolaris spicefera (Bainier) Subrum. was reported on rice, Bipolaris austailiensis (M. B. Ellis) Tsuda \& Ueyama was isolated from painted $\operatorname{wood}^{(4,5)}$. Bipolaris oryzae (Breda de Haan) Shoemaker causes brown spot of rice( ${ }^{(6)}$ and B. sorokiniana (Sacc.) Shoem causes Bipolaris leaf blight of wheat $^{(7)}$ in Bangladesh.

A study was conducted to identify the fungi associated with phylloplane of Gerbera spp. belongs to the family Asteraceae. During the period of this study B. hawaiiensis was isolated from healthy leaves of Gerbera aurantiaca (red flower). Leaf samples of $G$. aurantiaca were collected from Botanic garden, University of Dhaka during the month of February 2012. "Tissue Planting" method was followed for isolation of fungi using PDA medium (8). Alternaria citrii Ellis \& Pierce. Apud Pierce, Aspergillus flavus Link, Aspergillus niger van Teighem, Aspergillus terreus Thom, Cladosporium cladosporioides (Fresen). De Vries, Colletotrichum dematium (Pers. Ex Fr.) Grove, Colletotrichum dematium (Pers. Ex Fr.) Grove, and Pestalotia de Not were found to be associated with the healthy leaf samples of G. aurantiaca. Along with the above fungi an unknown species of Bipolaris was isolated from the Gerbera leaves. Morphological characters of the fungus were recorded on PDA .

Colonies of the fungus was black velvety. Hyphae pale to mid brown, smooth septate, 1 - $3 \mu \mathrm{m}$ diameters. Conidiophore was solitary, flexous, septate, pale to mid brown, up to $120 \mu \mathrm{m}$ long, but usually much shorter, 2 - $7 \mu \mathrm{m}$ diameter. Conidia straight, ellipsoidal, oblong, or cylindrical, rounded at the ends, pale to mid brown, 2 - 7 (mostly 5) pseudoseptate, $12-37(24.5) \times 5-11(8.2) \mu \mathrm{m}$. Conidia germinate from both poles (bipolar). A flattened hilum or point of attachment is seen on the basal cell of conidia (Figs 1. a-h and 2a-b)).

*Author for correspondence: <Prof.shamsi@gmail.com>. 

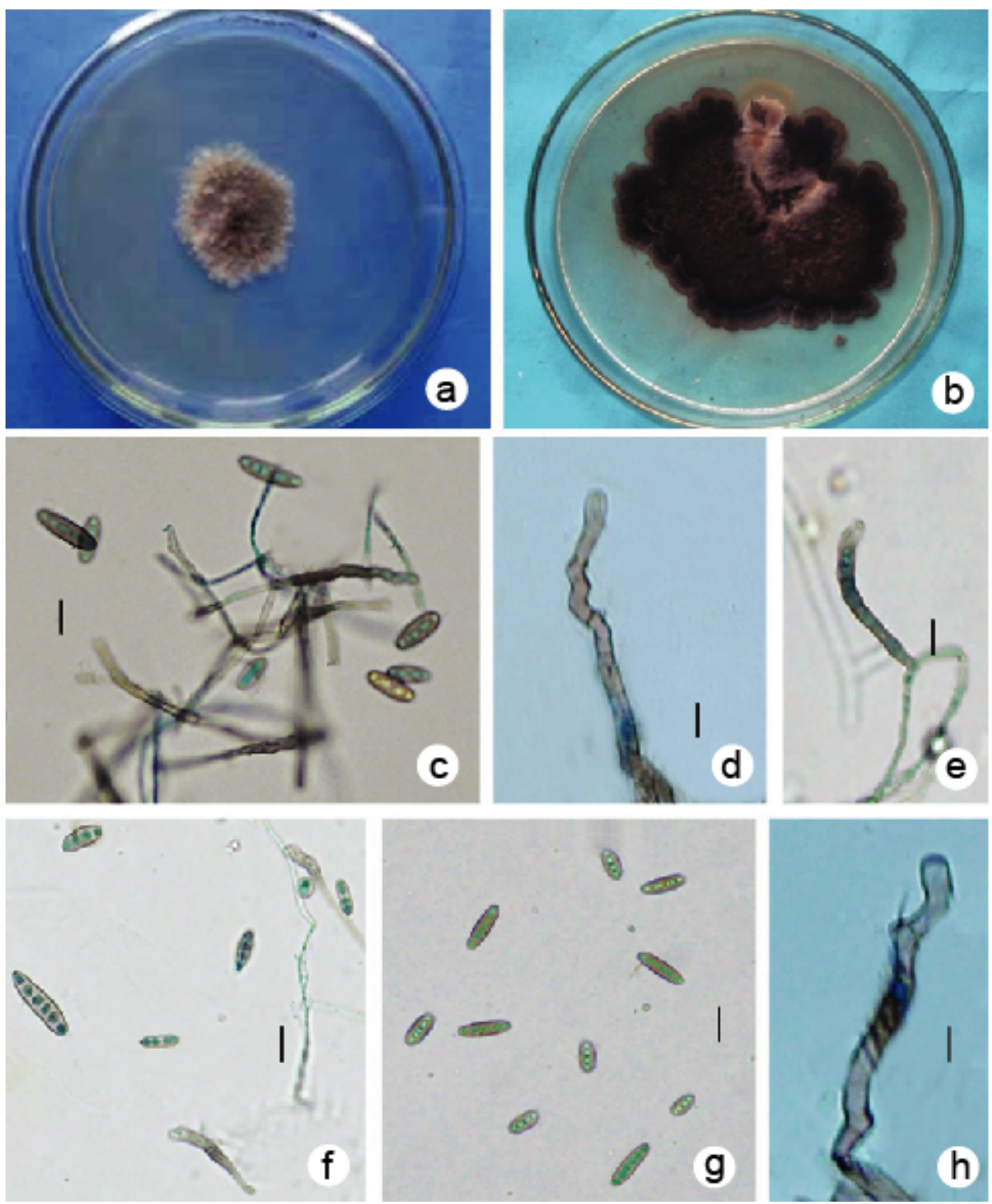

Fig. 1. Bipolaris hawaiiensis: A. 7 days PDA colony. B. 10 days PDA colony. C-H. Conidiophore and conidia. $(\mathrm{Bar}=50 \mu \mathrm{m})$.

The morphological characters recorded in the present study were compared with those reported ${ }^{(9,10)}$ and the fungus was identified as Bipolaris hawaiiensis. This is the first report on the association of fungi with Gerbera plant and occurrence of a human pathogenic species of Bipolaris in Bangladesh. 


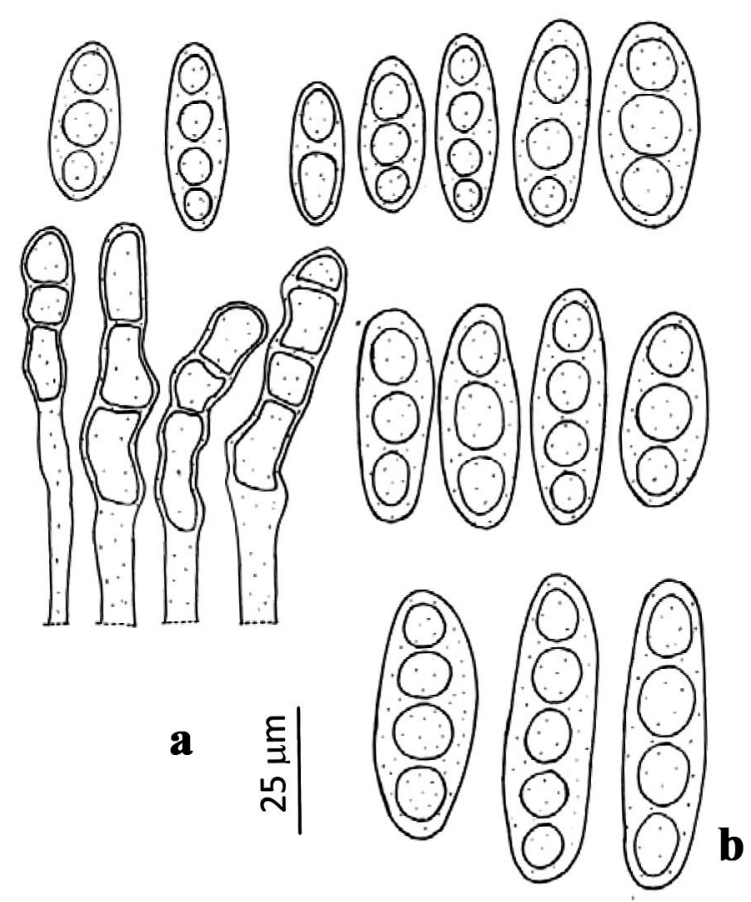

Fig. 2. Bipolaris hawaiiensis on Gerbera auratiaca (red flower) plant: a. conidiophore and $\mathrm{b}$. Conidia $(\times 2500)$

Bipolaris hawaiiensis (Bugnicourt ex M.B. Ellis) Uchida \& Aragaki com. nov. Specimen examined: Isolated from healthy leaves of Gerbera aurantiaca, Botanic Garden, University of Dhaka, Dhaka, S. Shamsi 3061, 10 February 2012.

\section{References}

1. Maskin SL, RJ Fetchick, CD Jr Leone, PK Shakey, MG Rinaldi 1989. Bipolaris hawaiiensis- caused phaehyphomycotic orbitopatyh. A devasting fungal sinusitis in an apparently immunocomptent host. Opthalmology 96(2): 175-179.

2. Chowdhury A, HS Randhawa, V Sing, ZU Khan, S Ahmed, S Kathuria, P Roy, G Khanna and J Chandra 2011. Bipolaris hawaiiensis as etiologic agent of allergic bronchopulmunary mycoses: first case in apaediatric patient. Med Mycol. 49(7): 760-765.

3. Anonymous 2013. URL:http:/Moldibrary.ca bopolaris.Opened on 30 March 2013.

4. Shamsi S 1999. Investigations into the sheath rot disease of rice (Oryza sativa L.) in Bangladesh. Ph. D. Thesis. Department of Botany, University of Dhaka, pp. i-xii +1-127.

5. Shamsi, S. and Z. Yasmin. 2009. Bipolaris australiensis (M.B. Ellis) Tsuda \& Ueyama - a new dematiaceous hyphomycetes record for Bangladesh. Bangladesh J. Plant Taxon. 16 (1): 91-93. 
6. Haque SMA, MA Begum, MS Rahman and MAT Mia 2002. Seedborne fungi of Boro rice as affected by fermer's seed processing activities. Bangladesh J. Plant Pathol. 18(1\&2):83-89.

7. Hyder, MMA and Fakir GA 1992. Fungi associated with wheat grains in Bangladesh and their pathogenic significance. Bangladesh J. Bot. 21(2): 173-180.

8. Anonymous . 1968. Plant Pathologist's pocket Book. Commonwealth Agricultural Bureau (CAB), Commonwealth Mycological Institute, Kew, Surrey, England, pp. 1-267.

9. Shoemaker RA 1959. Nomencleture of Drechslera and Bipolaris segregated from Helminthosporium. Can. J. Bot. 37: 879-887.

10. Unchida JY and M Aragaki. 1979. Etiology of Necrotic Flecks on Dendrobium Blossoms. Phytopathology 69: 1115.

(Manuscript received on 23 March, 2013; revised on 27 April, 2013) 